\title{
Citizens' Preferences for Development Outcomes and Governance Implications
}

\author{
Thomas Falk ${ }^{1}$, Tobias Vorlaufer ${ }^{2}$, Lawrence Brown ${ }^{3}$, Stephanie Domptail ${ }^{4}$, and Martin \\ Dallimer ${ }^{5}$
}

${ }^{1}$ ICRISAT

${ }^{2}$ University of Osnabruck

${ }^{3}$ University of Marburg

${ }^{4}$ University of Giessen

${ }^{5}$ University of Leeds

September 11, 2020

\begin{abstract}
People's preferences influence national priorities for economic development and ecological integrity. Often policy makers and development agents base their actions on unclear assumptions about people's preferences. This paper explores rural citizens' preferences for economic and ecological development goals and how they differ within and between communities. We collected data from three purposely selected communities representing dominant social-ecological systems in the transboundary CubangoOkavango River Basin in southern Africa. We used contingent ranking survey experiments, which are a novel methodological advance in policy related research. This included a qualitative experimental design process that provided a broad framing underpinning the research. The contingent ranking itself allowed us to simultaneously assess (i) participants' ranking priorities for the development goals; and (ii) participants' preferences for the ordering of those goals. We found relatively strong preference homogeneity within and between communities. Economic development attributes were given high priority across all communities. At the same time, all communities expressed a high preference for a healthy river system providing stable water quality and quantity. This does not mean that our respondents prioritized nature conservation. They showed low preferences for preserving biodiversity and forests which provide less important local benefits than water. This is of high governance relevance. The results point at development domains where policy makers can most likely expect stronger buy-in from citizens. Understanding citizens' preferences helps to better align national development priorities with what citizens want.
\end{abstract}

\section{Hosted file}

Trade-offs Okavango title page.docx available at https://authorea.com/users/356163/articles/ 479145-citizens-preferences-for-development-outcomes-and-governance-implications

\section{Hosted file}

Trade-offs Okavango main text.docx available at https://authorea.com/users/356163/articles/ 479145-citizens-preferences-for-development-outcomes-and-governance-implications 